\title{
SBÍRKOTVORNÁ A VÝZKUMNÁ ČINNOST JAKO FORMA KOMUNIKACE MUZEA S VEŘEJNOSTÍ (NA PŘÍKLADU VÝVOJE PRAVĚKÉHO ODDĚLENÍ NÁRODNÍHO MUZEA)
}

\author{
Karel Sklenár̆
}

Collecting and Research Activities as a Form of Communication between the Museum and the Public (on the Example of the Prehistory Department of the National Museum)

\begin{abstract}
Based on the example of the Prehistory Department of the National Museum, the present paper examines two of the ways in which the Museum has communicated with the public from the time of its foundation to, basically, the present: through the activities of collecting and researching. In the case of collecting activities, the text outlines how the proportion of donations and purchases along with the Museum's discoveries evolved depending on social, political and, for example, legal circumstances. In the case of research activities, it illustrates the significance of the overall context regarding the development of archeology and its institutional protection. An irreplaceable role in the whole process was, however, played by important personalities of the Museum's Archeology Department, such as J. L. Píč and J. Neustupný.
\end{abstract}

Keywords: National Museum - archaeology - J. L. Píč - J. Neustupný - collecting activities - archaeological researches

Contact: PhDr. Karel Sklenář, DrSc.; e-mail: zuzana.blahova@ff.cuni.cz

Z pohledu veřejnosti je archeologický terénní výzkum hlavní, ne-li jedinou pracovní náplní archeologů a archeologických pracovišst'. Ponechme stranou opačný názor častý u orgánů muzeím nadřízených, že pracovní výkon zaměstnanců se má omezit na péči o sbírky. Jisté je, že od počátků sběratelství a muzejnictví byl vlastní terénní výzkum nejvýznamnějším zdrojem prírůstků sbírek, přičemž zhruba od poloviny 19. století byl chápán hodnotový rozdíl mezi př́růstkem náhodně zachovaným, vytrženým z kontextu nadále neznámého, a nálezovým materiálem z rádně provedeného výzku$\mathrm{mu}$ (období prvotního pozitivismu v archeologii 70. a 80. let objevilo a zakotvilo pojem nálezového celku).

O odbornou stránku muzejní archeologické akvizice ale $\mathrm{v}$ tomto př́spěvku nejde. Povšimněme si spiše jiné, méně sledované stránky, totiž akviziční činnosti a tvorby sbírek jako prostředku komunikace mezi muzeem a veřejností, resp. společností. Tyto činnosti se totiž obvykle v souvislosti s tímto vztahem neberou v úvahu, ale pokud jde např́klad o archeologii jako jeden ze základních muzejních oborů, je to omyl, jak se hned ukáže.

Komunikace obecně vyžaduje ke svému uskutečnění (přinejmenším) dvě strany a totéž předpokládá i sbírkotvorná činnost, která má v zásadě dvě formy: pasivní, kde muzeum je př́ijemcem sbírkových prírůstků, a aktivní, kde samo vyvíjí činnost pro jejich získání.

První z nich má od počátku tradiční podobu převodu vlastnictví, bud' bezúplatného (ale ne vždy bezpodmínečného) od osoby žijící (dar) nebo zesnulé (odkaz), nebo úplatného (koupě). Jestliže koupě je záležitost víceméně komerční, dar nebo odkaz už přímo odrážejí vztah darujícího k muzeu, povědomí o jeho existenci a účelu. Význam daru jako akviziční formy v historii muzejnictví je nepř́mo úměrný vývoji aktivní (výzkumné) složky. Do druhé třetiny 19. století byla tvorba sbírek zásadně závislá na dárcích (téměř vesměs fyzických osobách) a jejich ochotě. K jejich motivaci se vytvářely různé cesty od vydávání provolání s apelem a zemské či národní vlastenectví až po př́mou osobní agitaci (obcházení $\mathrm{s}$ upisovacími listinami).

Vcelku ovšem - odmyslíme-li si vlastenectví, jež jako motivace s pokračujícím 19. stoletím pozvolna ztrácelo na váze to byla víceméně jednostranná cesta od muzea $\mathrm{k}$ veřejnosti s odezvou sice nadšeně vítanou a publikovanou (seznamy dárců v muzejních časopisech), ale přitom výrazně menšinovou. Tou zůstala tato akviziční složka i do budoucna, zejména pokud jde o pramenný materiál společenskovědních oborů, který u archeologických pramenů začal být chápán jako zboží - zprvu spíše jako prodejná surovina (kov, kosti), ve druhé polovině 19. století už i jako předmět obchodu se starožitnostmi.

Význam daru pro muzejní archeologické sbírky (zejména NM) je tedy ve 20. století obecně nízký a $v$ jeho průběhu stále klesá, až nakonec nehraje prakticky žádnou roli. Významný podíl na tom měl památkový zákon z roku 1958, prohlašující veškeré archeologické nálezy v zemi za majetek státu, s výjimkou drahých kovů bez nároku na nálezné. Teoreticky byl dar nahrazen institutem předání, v praxi si nálezci vykopané předměty spíše nechávali a začal se rozvíjet i černý obchod s nimi. Ideová motivace dárců už vymizela a finanční ve správném směru neexistovala. 
Vývoj situace zřetelně posílil význam aktivní formy akvizice, tedy vlastního působení muzea v terénu (povrchového průzkumu a destruktivního výzkumu - ,vykopávek“). Tato jistě nejnápadnější složka výzkumně-sbírkotvorné činnosti muzeí prošla během doby existence archeologických sbírek NM vývojem nejen odborným, ale i organizačním. V první fázi, kdy se o této složce dá hovořit (půlstoletí 1843-1893), výzkum v podstatě inicioval a financoval Archeologický sbor NM, korporace př́slušná do rámce Společnosti NM $^{1}$ a víceméně spravující její archeologické sbírky - v dobách fungování jejich kustoda (jako člena Sboru) nepřímo, v mezidobí 50. a 60. let (prostřednictvím asistentů sbírky) přímo. ${ }^{2}$

\section{První období (1843-1893)}

Vztah muzea a veřejnosti na poli archeologie lze sledovat teprve od roku 1843, kdy byl Archeologický sbor uveden do života. Do té doby bylo muzeum především doménou aristokratického okruhu svých zakladatelů a „střední stav“ (tj. přepokládaná veřejnost) s výjimkou několika ustanovených spolupracovníků-,,sbíratelư “ stál mimo; tito dobrovolní „,sbíratelé" představují ovšem první formu navázání vztahu muzea s veřejností na základě akvizice sbírkových předmětů.

Archeologickému sboru dali jeho zakladatelé do čela stanov úkol „české starožitnosti sbírati, chrániti a ve známost uvozovati“. Že uvozování ve známost znamená obracení se k veřejnosti (i když tehdy tím byla míněna především nečetná množina zájemců, „starožitníkư‘), je zrrejmé; méně už, že i sbírání, tj. budování sbírkového fondu akvizicemi různého druhu je vlastně opačný směr tohoto vztahu, a byl jím tehdy mnohem více než dnes.

Už sám Archeologický sbor (jako druhá korporace po sboru zkráceně zvaném Matice česká) byl zejména po své reorganizaci na počátku 50. let extenzí Společnosti NM do veřejného prostoru s posláním získávat pro muzeum sympatizanty a jejich prostřednictvím obohacovat sbírky, prípadně i rozpočet na sbírkotvornou činnost. Seznamy přírůstků sbírek NM z př́slušných let jasně dokládají, že tato cesta byla úspěšná a že dar byl v tomto prvním období zcela převládající formou obohacení sbírky, zatímco ke koupím prakticky nedocházelo. V darech je potom patrný nárůst po vzniku Sboru, což dokládá význam navázání určitého styku s veřejností.

Tuto tendenci radikálně posílil v roce 1850 případ nákupu tehdy druhé největší české archeologické sbírky (nezaostávající př́liš za rozsahem sbírky „starožitností“ NM), kterou vytvořil inženýr Josef Pachl v Praze. ${ }^{3}$ Potřeba zachránit sbírku před vývozem z Čech donutila muzeum souhlasit s přehnanou a na svou dobu obrovskou kupní cenou 6000 zlatých, kterou nemohlo ze svých fondů uhradit. Tehdy se obrátilo na veřejnost subskripční akcí, podobnou pozdějšímu sbírání na Národní divadlo, která vynesla částku dokonce o něco větší. Díky aktivitě výboru Společnosti NM (zejména F. Palackého) a sběratelů, navštěvujících potenciální sponzory nejen z vyšších vrstev, ale i např. ve čtenářských besedách mimo Prahu, si muzeum na omezenou dobu vytvořilo živý vzájemný vztah s veřejností. Nebyla to ani expozice (jako obvykle jediný styčný bod), ani výzkumná činnost, nýbrž právě činnost sbírkotvorná, která přivedla muzeum do zorného pole pozornosti širšího okruhu zemských vlastenců i národovců, navíc v těžké době začínající „,normalizace“ po ,pražském jaru“ 1848, která muzeu jako jeho opěrnému bodu vysloveně nepřála. O to byl výsledek cennější.

Úsek vlastního archeologického výzkumu NM měl v prvním období dlouho význam zcela okrajový, tím spíše, že archeologická sbírka po většinu této doby neměla vlastního řádného správce. První terénní akce úřednější povahy proběhly roku 1843 vlastně jako služební cesty kustoda J. V. Hellicha, přičemž skutečným archeologickým terénním výzkumem byla až druhá z nich u Poběžovic (financovaná hlavně externě - majitelem pozemku kn. Trautmannsdorffem, ale také pro jeho sbírky, nikoli pro NM). Jiný vztah k veřejnosti tyto akce neměly, a byly tedy pro muzeum spíše interní záležitostí. ${ }^{4}$

Důležitý krok byl učiněn v roce 1866, kdy se prokopávání pravěkého mohylového pohřebiště u Plava na Českobudějovicku stalo nejen první veřejnou výzkumnou akcí NM (přesněji Archeologického sboru), nýbrž i prvním příkladem spolupráce $s$ veřejností v tomto směru. Stalo se to jednak participací dvou vedoucích osob výzkumu - budějovického obchodníka Františka Stulíka, jenž lokalitu pro archeologii objevil a zčásti na vlastní náklad prokopával, a odborníka (v dobovém smyslu) Jana Karla Hrašeho, jenž byl Archeologickým sborem jako jeho člen vyslán a pracoval na jeho náklady. ${ }^{5}$

Výsledky jejich práce byly určeny pro sbírku NM a také se tam dostaly - poté, co Stulík uspořádal z nalezených předmětů $\mathrm{v}$ Českých Budějovicích krátkodobou výstavu jako v Čechách první výstavní prezentaci archeologie v dnešním užším smyslu, propagovanou i zprávami v denním tisku. Jestliže nedávná první ,archeologická“ výstava v českých zemích (akce spolku Arkadie v Praze 1861) byla ve skutečnosti umělecko-historická, tady se poprvé prezentovala skutečná archeologie pomocí výsledků vykopávek. ${ }^{6}$ Plavská akce roku1866 (přes souběžné nepř́iznivé válečné okolnosti) přinesla tedy nejen první významnou akvizici získanou vlastním terénním výzkumem (navíc zčásti darem významného spolupracovníka $\mathrm{z}$ řad veřejnosti, získaného prostřednictvím Sboru), ale i první a hned úspěšnou výstavu určenou jak $\mathrm{k}$ informaci veřejnosti, tak $\mathrm{k}$ získání dalších příznivců. Lze říci, že rokem 1866 začíná skutečný aktivní vztah archeologie NM k veřejnosti.

\footnotetext{
${ }^{1}$ Karel SKLENÁŘ, Společnost Národniho muzea v dějinách i v současnosti, Praha 2007.

2 Karel SKLENÁŘ, Archeologický sbor Národního muzea, in: 150 let Národního muzea, Praha 1968, s. 91-101. V obecnějším rámci Karel SKLENÁŘ, Obraz vlasti. Př́běh Národního muzea, Praha 2001; Karel SKLENÁŘ, Pravěká a raně středověká archeologie v dějinách Národního muzea, Fontes archaeologici Pragenses, 2014, roč. 40.

${ }^{3}$ Karel SKLENÁR̆, Český archeologický sběratel Josef Pachl, Sborník Národního muzea, řada A, 1996, roč. 50, s. 1-37.

${ }^{4}$ Karel SKLENÁŘ, Archeologická činnost Josefa Vojtěcha Hellicha v Národním muzeu (1842-1847), Sborník Národního muzea, řada A, 1980, roč. 34, s. 109-236. Bliže k výzkumům príslušná hesla in Karel SKLENÁŘ, Pravěké a raně středověké nálezy v Čechách do roku 1870, Fontes archaeologici Pragenses, 2011, roč. 36.

${ }^{5}$ Karel SKLENÁR̆, ,Mohyly plavské v Budějovsku“ (Archeologický výzkum z roku 1866 ve světle dokumentů), Časopis Národního muzea, řada historická, 1983, roč. 152, s. 1-26; K. SKLENÁR̆, Pravěké a raně středověké nálezy, s. 224-226.

${ }^{6}$ Karel SKLENÁ $̌$, Z historie archeologických výstav mimo muzea. (K 150. výroči výstav z let 1865 a 1866.), Zprávy České archeologické společnosti, 2015, Suppl. 98.
} 
Tradice archeologické výstavy, navázané na terénní výzkum, přes evidentní př́nosnost pro tento vztah bohužel nevznikla, na mimomuzejních výstavách př́štích desetiletí budou nálezy fungovat zase spíše jako kuriozity ve společnosti jiných druhů exponátů.

Mezitím se vyvíjely další dvě formy propojení archeologického výzkumu s veřejností, obě rovněž perspektivní. Jednou bylo pokračování muzejní výstavní prezentace ve vyšší podobě expozic Národního muzea (až do 60. let jediné a také nadále ještě po desítky let bezkonkurenčně nejvýznamnější muzejní instituce v Čechách): ${ }^{7}$ jestliže nevelká archeologická stálá výstavka na Hradčanech byla spíše skromnou snůškou starožitností, v budově v Kolovratské ulici (dnes Na Př́kopě) po roce 1846 vybudovali představitelé Archeologického sboru skutečnou muzejní expozici na úrovni své doby, odlišující již starožitnosti pravěké od středověkých a mladších, archeologické předměty od umělecko-historických památek. V polovině 19 . století tedy začíná působení archeologických složek muzea na veřejnost výstavní formou, ovšemže pasivní - zájemce musel přijít za archeologií a vyčíst poučení z instalace, která se nijak nesnažila vyjít mu vstříc nějakou systematickou úpravou či dokonce explanační složkou (to nebylo v té době zvykem). Navíc expozice jednou zbudovaná byla nadále už jen doplňována a zahuštována novými přírůstky, čímž ztrácela i původní přehlednost a ,vkusnost“", takže zájem veřejnosti nebudila, spíše odsudky domácích i zahraničních odborníků.

K expoziční formě je třeba říci, že na rozdíl od předchozích nebyla v prvním období plně doceněna. Zpočátku byla archeologie, jakási popelka ve srovnání s př́rodními vědami preferovanými skupinou zakladatelů NM, vystavována jako seskupení nepř́liš pohledných kuriozit, hlavně proto, že se od muzea vystavování očekávalo (resp. očekávali to dárci). S dospíváním vědeckého chápání oboru se archeologie stává poměrně důležitým aktérem národního kulturního a politického zápasu, ale ve výstavní prezentaci jako stále jediné formě muzejnického vztahu $\mathrm{k}$ veřejnosti se to nijak neodráží: až do druhé poloviny 19. století přetrvává pojetí archeologického pramene jako kuriozity v uspořádání neodrážejícím ani pokrok vědy, ani její společenskou angažovanost. Muzeum sbírku pouze předkládá rutinním způsobem vhodným nejspíše pro odborné návštěvy, její prrípadný výklad a použití ve veřejném ideovém zájmu přenechává jiným. Pokud tedy byly ojedinělé akviziční, výzkumné či výstavní (mimomuzejní) akce nástrojem navazování vztahů s veřejností, o expoziční činnosti archeologie v NM se to tvrdit nedá.

Aktivnější a působivější, ovšem zase s mnohem omezenějším dosahem (asi jako agitace ve srovnání s propagandou) byla archeologická osvěta. kterou rozvíjeli archeologové té doby - jmenovitě P. Václav Krolmus ve 40. a 50., P. František Petera Rohoznický v 60. a 70. letech 19. století. Oba badatelé, pracující s významnými finančními subvencemi Sboru, tj. NM - katoličtí kněží, disponovaní k tomuto úkolu profesionální schopností veřejného projevu a společenským

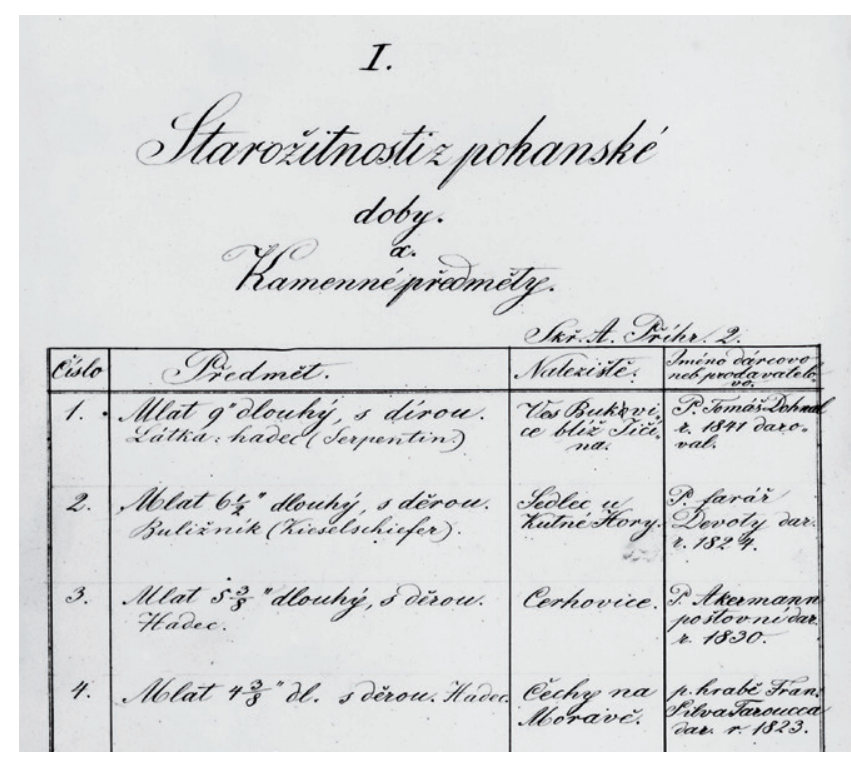

Obr. 1. Už nejstarší muzejní inventární knihy dokládají výlučnou roli dárců při tehdejší tvorbě sbírek (Vocelův inventář archeologické sbírky, 1850).

postavením, dodávajícím jejich slovům váhu - neúnavně poučovali veřejnost $\mathrm{v}$ dosahu svých průzkumů a výzkumů výklady o smyslu této práce a hodnotě archeologických nálezů pro zemské a národní dějiny, konkrétně pak o potřebě a záslužnosti jejich ukládání v muzeu. Oba tím byli veřejně známí, zejména Krolmus, z jehož činnosti v době jeho smrti (1861) pocházela čtvrtina až třetina archeologického materiálu ve sbírce NM. ${ }^{8}$ Zatímco Krolmus prováděl i demonstrační vykopávky pro zvané společnosti, Petera se zapsal do historie práce s veřejností první veřejnou archeologickou přednáškou, kterou přednesl s velkým úspěchem 25. 2. 1872 v Libni u Prahy o svých tamních nálezech (včetně jejich demonstrace). ${ }^{9}$ Tím byl založen další tradiční směr aktivního působení na veřejnost, který se ovšem rozvinul teprve ve 20. století.

Literárně zdatný Petera kromě toho jako první u nás bohatě využíval možností působit na veřejnost zprávami o nálezech v deníkovém a časopiseckém tisku, které vždy spojoval s výzvou k záchraně nálezů a jejich ukládání do muzea. Po ojedinělém prvním pokusu J. K. Tyla o návodnou povídku, vyznívající v témže smyslu (1846), ${ }^{10}$ to byly právě tyto Peterovy články, co začínalo budit zájem veřejnosti a založilo tradici propagace archeologie tiskem (vedle Vocelovy, Archeologickým sborem NM vydané ,,prostonárodni'“ příručky z roku $1845,{ }^{11}$ která ale zase tak prostonárodní nebyla - Petera se svými znalostmi lidu ovládal tento typ komunikace lépe). Nakonec je ale důležité, že všechny tyto produkty - at' Tylova povídka, Vocelovy brožury či Krolmusova a Peterova ústní i tisková osvěta - nezbytně vždy vrcholily upozorněním, že nálezy patří do NM a zdůrazněním jeho národního významu. Tato vícestranná propagace ústavu a jeho sbírek, typická hlavně pro období 50.-70. let (v 80. a 90. letech

Karel SKLENÁŘ, Archeologická expozice v počátcích Národního muzea, Muzejní a vlastivědná práce, 1968, roč. 6, s. 85-91.

${ }^{8}$ Karel SKLENÁŘ, Václav Krolmus a prehistorická sbirka Národního muzea, Časopis Národního muzea, Historické muzeum, 1965, roč. 134, s. 28-33; Karel SKLENÁŘ, Václav Krolmus. Život a dílo archeologa-romantika, Roudnice - Mladá Boleslav 2012.

9 Karel SKLENÁŘ, František Xav. Petera Rohoznický, první archeolog Prahy, Archaeologica Pragensia, 2018, roč. 24, s. 7-166.

${ }^{10}$ Karel SKLENÁŘ, Bohové, hroby a učitelé. Cesty českých spisovatelů do pravěku, Praha 2003, s. 76-78, 84.

${ }^{11}$ ANONYM (Jan Erazim VOCEL), O starožitnostech českých a o potřebě chrániti je před zkázou, Praha 1845. 
Jest wůbec známo, že znamenitá sbírka starožitností, jižto wrchní inžinýr, p. Pachl, w Praze chowá, našemu hlawnímu měslu a wlasti w králkém čase odñata bude, jestli ušlechtilých národomilâw snažením se nenaskyine prostréedkủw, kterýmiž by takowáto ztrála od nás odwrácena byla. Sbírka tato, obsahujići pres 1000 ćisel, - $\mathrm{z}$ nichžlo některé obecenstwu známy jsou $\mathrm{z}$ wyobrazeni, nalezajicích se w almanachu „Libuša“ od Klara, - takowou cenu do sebe má, že nynejjši pokolení Čechủı mrawně takmēr zawázáno jest, ji potomkům zachowati a w majetnost národa ěeskélıo obrátiti. Wýznamné, pro wědu historickou dâležité památky tyto, kdyby nyní zemi a národu, kde pûwod jich jest, odñaty byly a do ciziny zanešeny, nemohlyby wíce na zpûsob předmětû príriodowědeckých jinými tohoto druhu památkami býti nahraženy, byt $\mathrm{i}$ potomkowé naši sebe wětšich obèti $\mathrm{k}$ získání jich snášcti chtěli. Žila by toliko w paměti lidu našeho

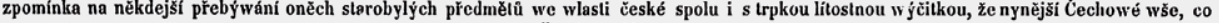
možno bylo, nečinili, aby tento poklad národu uchráněn a $\mathbf{k}$ česhému Afuseum připojen byl.

České Museum wedlé znění základního listu swého $\mathrm{k}$ tomu jsouc ustanoweno, aby dějepisni památky a ostalky dáwnowěké wzdèlanosti ěeského národa sbíralo a opatrowalo, základní jistinu swou tak wysililo nákladem na zř́zení nynějš́i mistnosti swé wedeným, že mu naprosto možno neni, z proslředků swých zakupní cenu sbírky nadřečené, toliž $6000 \mathrm{zl}$. stŕ. položiti.

Jediná naděje, alyy národni tento poklad wlasti zachowán byl, spočiwá na penẽžitých prispěwwcích ěeských národomilû.

Wysoce slawný zemský wýbor byl prwni, jenž ochotnost swou projewil, k zakoupeni sbirky tú 2000 zl. slř. obělowati.

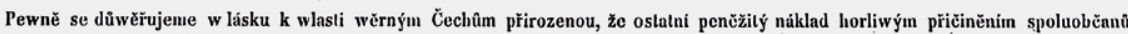
našich se $\mathbf{w}$ králkém éase sejde a koupí oněch národnich starobylosti se uzawřc. Necht jen kažltỷ $\mathbf{k}$ milé wlasti se wërně pr̆iznáwajic

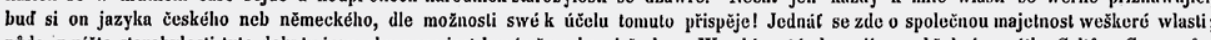
pûda, z nižto starobylosti tyłto dobyly jsou, skropena jest kriví německou i českou. Wc sbírce tú chowaji se pohřcbní památky Celtûw, Germanûiv i Slowanůw, kteréžlo, až se jich dotkne blesk wẽdy, zde pozemského takřka wzkřišeni swélıo dojdou. Duch míru wane nad těmito ostalky, a zpyiujíci wěda, stawíc na základẽ jejich úwahy swé, stane se snad běhen času ohniskem, w němžlo národní nedorozumění zanikne, a rozdwojené mysle mocným kouzlem wědy a lidskosti spráteleny budou a sjednoceny!

Jednotliwé peněžité prisisěrwky spolu se jmény welectěných prispiwiwatelû uweřejněny budau.

Mimo p. p. sběratelele, jichžlo jména swrchu nadepsána jsau na těchto lislech, prijijimají téż $\mathbf{k}$ tomulo úcelu peněžité přispěwky kněhkupectwi J. G. Calte (Tempský, starom. malé náměstí č. 458) a kněllkupectwi Fr. B̈icuenače (w domě českého Huseum).

W Praze dne 19. Dubna 1850

\section{Od archeologického sboru českého Museum.}
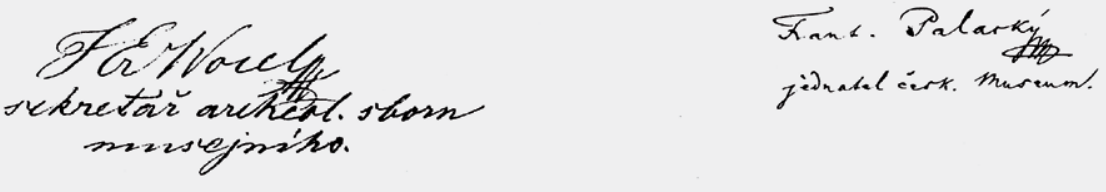

Obr. 2. Finanční sbírka na zakoupení archeologické kolekce Josefa Pachla pro Národní muzeum (1850) byla největší akcí tohoto druhu v českých muzeích 19. století (provolání na první straně upisovacího listu, vydaného sběrateli F. B. Mikovcovi).

pokračovaly v tomto směru četné ,,archeologické povídky“ Klimenta Čermáka, nikdy neopomíjející v apelativním závěru upozornit na $\mathrm{NM}^{12}$ ) přinášela doložitelné výsledky.

Jde tedy už v prvním období o obě linie, po nichž archeologie NM mohla hledat a navazovat styky s veřejností za účelem budování sbírek a které se vlastně do moderní doby př́liš nerozmnožily: o linii akvizic pasivních (dary, nákupy) i aktivních, jež vycházely z terénní výzkumné, tedy odborné činnosti pracovníků bud' přímo muzejních nebo $\mathrm{k}$ muzeu přidružených a jím v různé míře financovaných.
Tyto činnosti vytvářely sbírkový fond dostatečně početný a kvalitní, aby sloužil jako další prostředek ke komunikaci s veřejností a působení na ni formou výstavní.

Ostatně o tomto prvním období jako celku platí, že uvedené vztahy byly v zásadě náhodné, přetržité, krátkodobé a až na zmíněné výjimky neefektivní. Nepochybně tu působil jev patrný v NM nejen v archeologii, zejména v pozdější fázi období: určitá sebestředná uzavřenost, odtažitost, soběstačnost až povýšenost. Dobře to ilustrují vztahy k menším, regionálním muzeím a muzejním spolkům, vznikajícím 
od 60. let. V prvních případech ještě NM dokázalo nacházet s nimi společnou řeč, zejména když uznávaly jeho vedoucí roli, nárok na lepší nálezy a vzor hodný plného následování - tak jako v roce 1864 vzniklá Včela Čáslavská, vůbec první životaschopný ,archeologický a muzejní spolek“ mimo Prahu, s osobními vazbami na Archeologický sbor. ${ }^{13}$ Později si NM uvědomilo, že mu v nich vlastně vyrůstá konkurence v akviziční činnosti, dosud až pohodlně monopolní, a zaujalo k nim (zhruba počínaje druhým obdobím) opačný postoj. Přitom si ale jen někteří uvědomovali, že malé „krajinské“ muzeum má proti NM zásadní výhodu právě v těsné vazbě na veřejnost regionu, reprezentovanou jeho muzejním spolkem, souvisle se k ní obrací a získává ohlasy své práce i nové podněty, orientuje na ni svou výstavní činnost neomezovanou na stálé expozice; obvykle polytematické (ale skoro vždy archeologii zahrnující) „krajinské výstavy“ byly právě živým typem krátkodobého výstavnictví, které v NM dosud chybělo, protože jeho potenciál v probouzení zájmu veřejnosti nebyl pochopen. NM se tímto způsobem od veřejnosti do jisté míry odřezávalo.

\section{Druhé období (1893-1911)}

K zásadní změně došlo na počátku 90. let 19. století, kdy v nově otevřené budově NM bylo zrrízeno samostatné pravěké (prehistorické) oddělení (1893) a jeho vedením pověřen prof. Josef Ladislav Píč. ${ }^{14}$ (Mluvíme-li od této chvíle o archeologii v NM, máme na mysli právě toto oddělení, protože o málo dříve, roku 1892 vzniklé oddělení archeologie historické bylo nadále vedeno historiky umění s převážným důrazem na tento a př́buzné směry a archeologie v moderním smyslu se tam objevovala až do 20. let jen nesouvisle a okrajově, i potom jen nevýrazně.)

Neúnavná aktivita J. L. Píče dokázala brzy změnit k lepšímu mnohé v archeologickém oboru na půdě NM, v neposlední řadě i jeho vztah $\mathrm{k}$ veřejnosti resp. společnosti v Čechách. Specifické ovzduší spolupráce se bohužel opíralo jen o jeho mimořádnou osobnost a s ní také odešlo. Projevovalo se především ve dvou směrech: výzkumném a výstavním, přesněji (ve zvykové české muzejní terminologii) expozičním. Pokud jde o terénní výzkum, nebylo předchozí období 70. a 80. let, kdy archeologii víceméně jako provizorium spravovali nádavkem ke svým fondům muzejní úredníci jiných oborů - prehistorickou snaživý archiváŕ Václav Schulz, historickou nepř́liš dbalý knihovník A. J. Vrt'átko - nijak aktivní. Po odborné stránce činnost ovlivňoval Archeologický sbor, který v tomto období žádné významné výzkumy neinicioval a spoléhal jednak na soukromou činnost několika svých činorodých členů, jednak, a to hlavně, na dary; přitom ale propagaci sbírek neprováděl. Archeologie jako celek nevybočovala tehdy z určité obecné izolace od moderních myšlenkových proudů, kterou mnozí současníci muzeu vyčítali.

Už v tomto směru způsobila extrovertní společenská povaha a široké styky prof. Píče výraznou změnu. Na přelomu
80. a 90. let dokázal Píč rychle vybudovat a volně zorganizovat svoji „družinu“ - neformální přátelské společenství archeologů amatérů (jiní nebyli), tvořenou pevným jádrem několika v terénu aktivních, víceméně osobních přátel a vnějšími okruhy zájemců či sympatizantů a podporovatelů. ${ }^{15}$

Společensky vzato, pocházel celý tento kolektiv ze středních vrstev zejména technické inteligence (klíčovou roli tu hrála „sít“" vedoucích pracovníků středočeských cukrovarů), osob vesměs zámožných, které jednak v archeologii samy prakticky pracovaly (terénní výzkumy, zejména záchranné), jednak ji podporovaly financemi i vlivem. To mělo velký význam, protože od vzniku prehistorického oddělení přestalo NM finančně dotovat výzkumy přes Archeologický sbor a poskytovalo určitou částku prostřednictvím ročního rozpočtu oddělení, ta ale prakticky nebyla vyšší než dříve, to znamená minimální, a nemohla už být zvýšena z jinak získaných prostředků Sboru (ten sám, řízený rovněž Píčem, se stal vlastně doplňkem oddělení a postupně ztrácel význam).

Efektivním napojením na mimomuzejní veřejnost a její finanční zdroje (byt' především v rozsahu „Píčovy družiny“ a jejích dalších styků - „vnějších okruhů“) dokázal Píč v 90. letech rozvinout mimořádně rozsáhlou terénní činnost ve prospěch muzejních sbírek, a naopak za účasti odborně schopnějších členů družiny souvisle informovat veřejnost o výsledcích této činnosti prostřednictvím seriálů nálezových zpráv v časopise Památky archeologické, samostatných publikací i zpráv v novinách a časopisech. Lze říci, že v 90. letech byla česká veřejnost poprvé soustavněji informována o archeologických nálezech a pracích a různými vazbami v této sfére angažována; dochované prameny (široká korespondence J. L. Píče, ${ }^{16}$ seznamy dárců do sbírek NM) ukazují, že zájem takto probouzený se šśřil daleko za okruh „družiny“.

Zásluhu o to měl i druhý ze zmíněných směrů - činnost prezentační, resp. expoziční. Přišla poněkud opožděně za terénním výzkumem, což ovšem bylo logické: až hektická výkopová činnost družiny byla vyvolána potřebou rozmnožit dosud celkem nevelkou a málo významnou prehistorickou sbírku NM novými a odborně hodnotnými fondy, aby byla schopna splnit expoziční úkol a plně využít tři sály přidělené jí v prvním patře nové budovy na Václavském náměstí. Trapný stav archeologické expozice NM v posledním období staré budovy na Př́ikopě a značný rozsah těchto tří sálů, které naprosto nebylo možno zaplnit starou sbírkou, byly pro Píče dokonce zřejmě hlavním důvodem badatelského rozmachu. Zároveň $\mathrm{s}$ tím $\mathrm{v}$ něm kolektivní povaha tohoto díla vzbudila či podpořila myšlenku, že dobrá expozice musí nějakým způsobem navázat vztah s návštěvnickou veřejností, u tehdejších expozic obvykle ještě zcela absentující.

Maje tuto okolnost na zreteli, vybudoval zde Píč postupně v letech 1894-1896 a do prvních let 20. století doplňoval prehistorickou a protohistorickou expozici evropského významu, která se s dílčími úpravami meziválečného období dožila až válečných 40 . let, kdy byla okupanty násilně zlikvidována ve prospěch nacistické výstavní propagandy.

\footnotetext{
${ }^{13}$ Karel SKLENÁŘ, Význam „VČely Čáslavské“ v počátcích českého regionálního muzejnictví, in: Drahomíra NovÁKová (ed.), Muzejní spolky včera a dnes, Č́slav 2011, s. 9-13.

${ }^{14}$ K. SKLENÁŘ, Vznik prehistorického oddělení Národního muzea v roce 1893, Časopis Národního muzea, řada historická, 1984 , roč. 153, s. 128-145.

${ }^{15}$ Karel SKLENÁR, Družina profesora Píče. Národní muzeum a zlatý věk neprofesionální archeologie v Čechách, Sborník Národního muzea, rada A, 1993, roč. 47, č. 3-4, s. 1-50+ př́il. I-VIII.

${ }^{16}$ I. GOŠOVÁ, - K. SKLENÁŘ - M. BĚLIČOVÁ, Josef Ladislav Píč - inventář osobního fondu, Praha $1993-1994$ (Archiv Národního muzea, rozmnož.).
} 
Závěr 19. století konečně (s novou budovou, novými lidmi a novou sbírkou) přinesl do NM prezentační dílo na špičkové úrovni doby. Píčova expozice pravěku a raného středověku Čech byla sice ještě pořád ,,archeologická“, tj. stála na prezentaci materiálu z vykopávek, ale měla už prvky moderních výstav, zejména se tu vedle exponátů originálních (těch bylo dostatečné množství, takže nevznikla potřeba užití kopií) poprvé objevila složka substituční - plastické stolové modely významných hradišt' (Stradonice, Libice) a doprovodné obrazy krajinářské povahy, zobrazující místa význačných objevů a výzkumů (Stradonice, jihočeské mohyly). Tím byla expozice oživena a přibližena běžnému návštěvníkovi. Složka explanační nebyla rozšířena podstatně (texty obecnější povahy se stále ještě neužívaly - při poměrně řídkém provozu byly někdy suplovány výkladem doprovázejícího pracovníka či hlídače v sálech), ale zdokonalena v tradičním úseku popisků $\mathrm{k}$ předmětům - formálně i obsahově. Popisky sice uváděly jen lokalitu - údaj vhodný k navázání dotyku s geograficky zainteresovanými návštěvníky - a název předmětu, ale byly jimi důsledně opatřeny všechny podstavce $\mathrm{k}$ exponátům a navíc (tak jako nikdy předtím a nikdy potom) velmi často obsahovaly i údaje o dárci, čímž se v dané společenské situaci jmenovaný reprezentoval a zároveň podněcoval $\mathrm{k}$ další činnosti pro muzeum. Vzhledem $\mathrm{k}$ povaze muzea jako zemského ústavu byly popisky navíc dvojjazyčné, české a německé. Takto i expozice vytvářela či posilovala vazbu zájemců z řad veřejnosti k, ,jejich“ muzeu.

Píčova expozice pravěku a protohistorie Čech patřila ve své době $\mathrm{k}$ nejmodernějším, což uznávaly nejen odborné návštěvy $\mathrm{z}$ ciziny, ale $\mathrm{i}$ běžní návštěvníci muzea, jak je vícekrát doloženo. V nesrovnatelně větší míře než předchozí skromné expozice na Př́kopě dokázalo toto výstavní dílo oslovit veřejnost, což se pak odrazilo i v akvizicích sbírky. Přinášelo důraz na odbornost a zároveň naučnost muzejní prezentace (zatím stále jen výstavní); to je ovšem směr, který může sledovat jen ústřední muzeum. Zříká se tím ale nástrojů, které vlastivědně pojatým regionálním muzeím zůstávají a pomáhají jim v blízkém vztahu k veřejnosti: tam kde ústřední muzeum jako prezentace celé země oslovuje odborníky a lidi s vyšším kulturním uvědoměním, regionální muzeum klade stále důraz na krajovou zajímavost věcí návštěvníkům důvěrněji známých a důsledným uváděním místních názvů a jmen dárců si zajišt’uje vazbu na veřejnost, ztělesňovanou nejspíše muzejním spolkem.

Souhrnně lze říci, že muzejnické dílo prof. J. L. Píče, ${ }^{17}$ dovršené v první dekádě 20. století, bylo prvním vrcholem ve vztahu prehistorické archeologie NM (a v rámci NM zdaleka nejen jí) $\mathrm{k}$ veřejnosti - př́mém, pokud šlo o terénní výzkum a jím získávané obohacení sbírek, neprímém, pokud jde o působení expozice (reflektovaný vliv). Nelze nezmínit další významný jev - akvizice celých soukromých sbírek, které se ovšem děly téměř vesměs za úplatu. Rozhodně právě díky Píčovi a jeho okruhu byla archeologie na sklonku „dlouhého“ 19. století v české veřejnosti poměrně známá, stejně tak i on sám jako její představitel až synonymní ztělesnění pro běžného zájemce (něco jako v meziválečné době brněnský prof. Karel Absolon pro archeologii československou), a to se samozřejmě odráželo $\mathrm{v}$ zájmu a podpoře muzejní sbírky

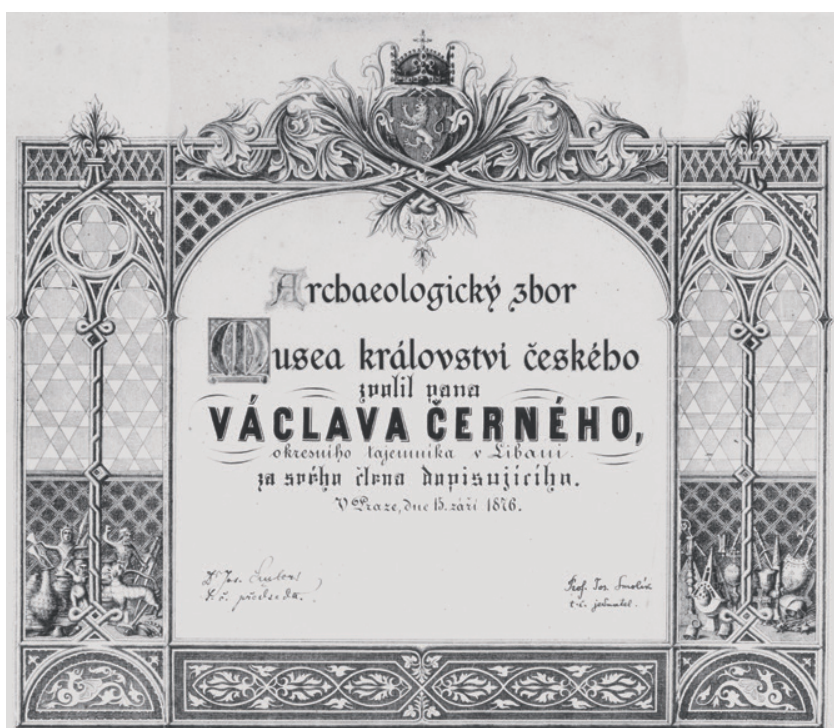

Obr. 3. Nejčinnější příznivci Muzea a dárci do sbírek bývali voleni členy Archeologického sboru a tím upevněn jejich svazek s NM.

zejména ve vzdělaných kruzích (např. v učitelstvu). Na půdě NM byla s ním souměřitelná jedině popularita a veřejný význam prof. Antonína Friče v prrírodních vědách.

\section{Třetí období (1911-1945)}

Tragická smrt prof. Píče a brzy následující léta první světové války znamenala tvrdý předěl, po němž už ze scény mizí takřka vše dříve důležité, nastupují nové poměry a noví lidé, v mnohém záměrně přerušující tradici. Vlády v muzejní archeologii se důsledně ujala strana Píčových odborných odpůrců z mimomuzejních kruhů, soustředěná spíše na teoretickou než na terénní práci. Přestože řízení oddělení se nakonec ještě těsně před válkou ujal archeolog spíše praktický se zkušeností z venkovského muzea - Albín Stocký (k němuž sem ovšem přichází i Niederlův žák Josef Schránil, čerstvý absolvent univerzitního studia archeologie bez muzejních zkušeností), meziválečná prehistorie v NM se jaksi spíše uzavírá do sebe. Zčásti nebylo nutné navazovat na činnost prof. Píče a jeho družiny a posilovat vztahy $\mathrm{k}$ veřejnosti, protože expozice byla vybudována a podle dobového mínění stačilo ji tu a tam korigovat podle nových poznatků (výtvarné řešení tehdy neexistovalo a vznik i další úpravy expozice v kompetenci správců sbírek záležely jen v sestavení či přeskupení exponátů ve skř́ínových, pultových či stolových vitrínách) a zčásti to ani nebylo možné, protože tradiční Archeologický sbor přežil válku už jen formálně, brzy se vytratil a zanikl. Zanikla i Píčova družina a její svět, nové útvary vznikaly už mimo muzejní půdu a vztahy mezi archeology 20. let měly v souvislosti s postupující profesionalizací i zápasem o převzetí vedení v oboru poněkud jiný charakter.

$\mathrm{V}$ poválečném období se začala vytrácet ochota $\mathrm{k}$ darování nálezů muzeu bez finanční náhrady a větší podíl tak získaly koupě celých sbírek, vytvořených předválečnými i poválečnými amatéry - pokud ovšem muzeum mělo potřebné prostředky, protože požadavky prodávajících se zvyšovaly spolu se zájmem veřejnosti; proto některé významné

\footnotetext{
${ }^{17}$ Karel SKLENÁŘ, Archeolog Josef Ladislav Píč jako muzejník v Národním muzeu, Časopis Národního muzea, řada historická, 2013, roč. 182, č. 3-4, s. 54-102.
} 
kolekce (jako sbírka J. Palliardiho) přes často zdlouhavá jednání o ceně nakonec muzeu unikla.

Vymizel však i aktivní podíl zainteresované veřejnosti na terénních výzkumech NM, jimž nyní už konkuroval zejména nový Státní archeologický ústav. Jejich financování (stále skromné) bylo nyní jen na muzeu samém a - ztěžováno rychle po válce rostoucími nároky dělnictva na mzdy spolu s odcházením nadšené amatérské generace 90. let omezovalo se v podstatě na drobné záchranné zásahy; větší výzkumy (Stocký ve Stradonicích 1929, Schránil v Čelákovicích-Záluží ve 30 . letech) byly výjimečné. Podpory mimomuzejním badatelům na výzkumy, přinášející dříve muzejním sbírkám určitý prospěch, byly už prakticky zrušeny, a tak padla další vazba na veřejnost.

Denní tisk (Národní listy, České slovo, Právo lidu, Venkov), zvyklý již přinášet „lokálky“ o archeologických nálezech a „vykopávkách“ zejména v Praze a okolí, referoval o těchto akcích poměrně často a udržoval tak jisté veřejné povědomí o této činnosti. O posílení tohoto vztahu a budování vazeb však nebyl zájem.

Ale ve stínu zaběhnuté praxe se chystala změna, jejímž nositelem se měl stát další mladý archeolog, nastoupivší do oddělení roku 1925 - Jiří Neustupný. V jeho osobě se o deset let později ujímá vedení oddělení osobnost založením a zaměřením nemálo připomínající J. L. Píče. Neustupný doceňoval potřebu obracet se $\mathrm{k}$ veřejnosti a získat od ní ohlas, případně i spolupráci. Ve svých počátcích nemohl své záměry ještě plně rozvinout, tím spíše ne za další války a okupace. Nicméně počátky obratu jsou již patrné.

V terénní činnosti zatím pokračovala určitá profesionální uzavřenost a menší akce přiměřené muzejnímu rozpočtu. Fenomén „Píčovy družiny“ se už ve vztahu k veřejnosti opakovat nemohl: byl nerozlučně spojen s poslední fází převahy amatérismu $\mathrm{v}$ archeologii, kdy jednotící osobnost významného profesionála odborně zaštit'ovala, ovlivňovala a korigovala a samostatnou práci neškolených milovníků archeologie. Jakkoli ve 30. letech bylo odborníků ještě nemnoho a metody i techniky terénního výzkumu se od Píčovy doby ještě př́iliš nezměnily, podobné početné a téměř oficiální angažmá amatérů nebylo už z hlediska profesionálů únosné ani žádoucí. Bylo sice ještě několik kvalitních amatérů nové generace s dobrými výsledky (např. B. Dubský, F. Dvořák), ti však pracovali už samostatně a pro muzea svých regionů.

Za této situace stoupá ve vztahu muzea a veřejnosti význam muzejní prezentace, což Neustupný dobře pochopil. Začíná systematická modernizace zastarávající Píčovy expozice, a to směrem od „čisté“ archeologie k formám přátelštějším vůči běžnému návštěvníkovi. ( $Z$ tohoto hlediska spíše sporný byl zásah z roku 1925, kdy dvojjazyčné česko-německé štítky exponátů byly v čerstvém ještě republikánském nadšení vyměňovány za české; důsledně se to pak provedlo r. 1938, ne nadlouho - 1940 zavedeny německo-české a po roce expozice zrušena.) Na prvních zásazích $\mathrm{v}$ eneolitické části $\mathrm{v}$ roce 1939 se to $\mathrm{z}$ vnějších důvodů ještě celkem neprojevilo, ale markantnější a pozoruhodnější je snaha Neustupného o komplexní působení výstavní činnosti propojením s dalšími formami styku s veřejností.

Vidíme tu kvalitativní posun v podobě prvku, který nemá předchůdce $\mathrm{v}$ minulosti oddělení, ale je nový: jde o krátkodobé tématické výstavy, pořádané $\mathrm{v} N \mathrm{NM} \mathrm{v}$ prvních válečných letech, kdy expozici nebylo možno měnit (ostatně byla

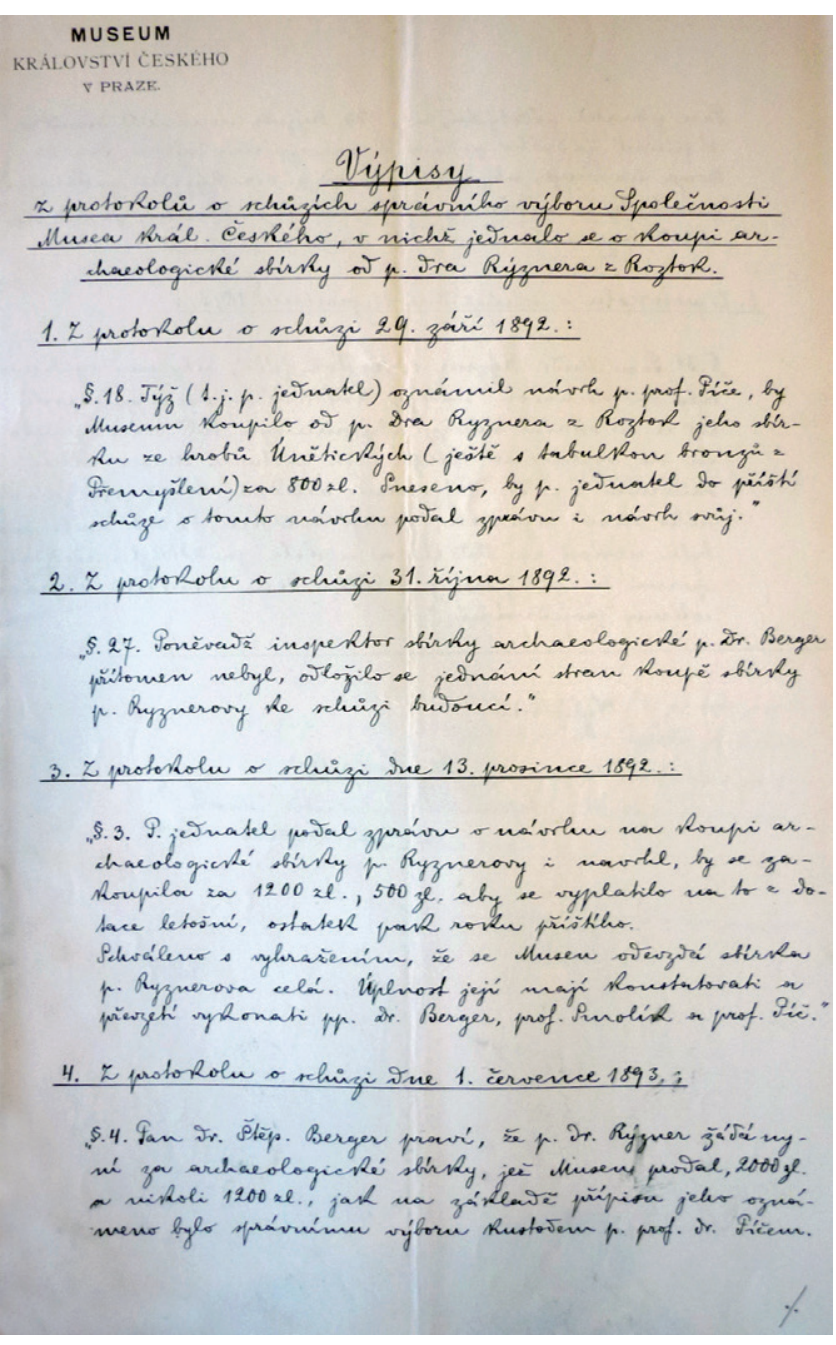

Obr. 4. Při nákupu soukromých archeologických sbírek vycházela iniciativa naopak většinou od pracovníků Národního muzea (záznamy z jednání o koupi významné sbírky Čeňka Ryznera, 1892).

brzy zlikvidována). Za této situace využil Jiří Neustupný odlišné prezentační formy, která dosud nebyla v NM obvyklá: teprve současně přicházela s touto formou ve větší míře knihovna, ale prehistorie navíc překročila se svou expoziční činností hranice muzea instalací nevelké tematické výstavy Lov v pravěku na Hospodářské výstavě v Praze roku 1939.

V muzeu samém šlo nejprve o spíše provizorní pokus $\mathrm{s}$ výstavou řeckých a římských památek v českých souvislostech (1938-1939), ale nakonec o úspěšnou výstavu Pravěké obřadní památky (1940-1941), když vlastenecký pokus o námět Nejstarší Slované v Čechách pochopitelně neprošel přes německou cenzuru. Pak už skončily výstavy vůbec.

Krátkodobá výstava sama o sobě je formou dynamickou (v protikladu ke statičnosti, jež přes možné úpravy je základní vlastností „trvalé“ expozice), dovoluje oslovit návštěvníka $\mathrm{v}$ určité tematicky úže vymezené, a proto lépe, detailněji prezentovatelné záležitosti. V režii Neustupného se však výstava spojila $\mathrm{s}$ dalšími formami muzejní prezentace a komunikace, dosud využívanými málo nebo vůbec ne. To druhé platí zejména o veřejných přednáškách námětově navazujících na výstavu, rozšiřujících a prohlubujících její sdělení ve prospěch zaujatější části návštěvníků, což zpětně vytváří nebo posiluje jejich stálejší vztah $\mathrm{k}$ muzeu. ( $\mathrm{O}$ veřejné přednášky 
s demonstracemi sbírkových předmětů se NM pokoušelo už od 20. let, ale tehdy ještě samostatně bez expozičních vazeb.) Zákaz českých přednášek r. 1941 ukončil i tuto formu.

Kromě toho Neustupný jako další variantu rozšířeného působení výstavy napsal a (mimo NM) vydal odborně popularizační brožury, které zpracovávaly námět v širších souvislostech: Náboženství pravěkého lidstva v Čechách a na Moravě (1940) a Pohřbívání žehem v pravěku Čech a Moravy (1941). Nebyl to sice prímo katalog výstavy - ty ještě nebylo v NM zvykem vydávat, vycházely nanejvýše souhrnné stručné průvodce po všech expozicích hlavní budovy muzea - zato ale popis vzájemné vazby vystavených částí sbírkového fondu a jejich zasazení do (pre)historického rámce měl trvalejší hodnotu, zvláště $\mathrm{v}$ době, kdy česká odborná literatura trpěla už různými, stupňujícími se omezeními. V první, přece jen ještě volnější polovině války, okupace a Protektorátu nastoupila tedy muzejní archeologie novou cestu $\mathrm{k}$ veřejnosti, úspěšnější o to, že českému kulturnímu publiku zbýval stále menší prostor a česká historie včetně té nejstarší získávala stále větší pozornost. Z hlediska tématu tohoto prríspěvku ale nelze přehlédnout, že úloha výzkumné a sbírkotvorné činnosti proti předchozímu období výrazně poklesla a převzal ji úsek prezentační.

\section{Čtvrté období (1945-1968)}

Možnost pokračovat $\mathrm{v}$ nastoupené cestě přišla až po válce a byla plně využita. V zásadě můžeme tuto fázi vývoje označit jako periodu expozičních pokusů a její souběh s vrcholným obdobím Jiř́ího Neustupného $\mathrm{v}$ čele prehistorického oddělení není náhodný. Teprve nyní mohl Neustupný plně rozvinout své představy o vztahu muzea a veřejnosti.

Projevilo se to už na úseku akvizic sbírkových fondů, kde možnosti nákupu sbírek byly ještě skromnější než před válkou (konfiskace německých a kolaborantských sbírek byla $\mathrm{z}$ hlediska vztahů $\mathrm{k}$ veřejnosti formou poněkud jednostrannou a krátkodobou). Za této situace stoupl význam vlastní sbírkotvorné činnosti. Se zařazením archeologických prací do Státního plánu základního výzkumu (SPZV) skončila éra početných menších záchranných výzkumů a navázáním na celostátní program výzkumné činnosti $\mathrm{v}$ rámci pětiletých hospodářských plánů (,pětiletek“) se objevila možnost provádět i větší, systematické badatelské výzkumy na místech záměrně vybraných, a tedy získávat i vědecky hodnotnější soubory nálezů.

Tím vstoupila archeologická terénní práce oddělení do širšího, veřejného rámce a stala se součástí společensky uznaných úkolů. Poměrně příznivé organizační a finanční podmínky 50. a zejména 60. let ve vazbě na celostátní plánování a ne zcela harmonickou spolupráci s již dominantním Archeologickým ústavem (ČSAV) dovolily oddělení dosáhnout vrcholu v celé historii jeho terénních výzkumů (zejména dlouhodobé akce na raně středověkém hradišti Libici nad Cidlinou a keltském oppidu u jihočeského Třísova).

Zapojení do SPZV přineslo také určité zveřejnění práce NM napřr. formou obhajob řešení úkolů a širší zpravodajství o jejích výsledcích na půdě ČSAV nebo v odborném i denním tisku. Práce tak vystoupila $\mathrm{z}$ mezí mateřské instituce a propojila se s archeologickou prací jiných organizací.

Na druhé straně převedení záchranné činnosti do kompetence Archeologického ústavu a odumírání Společnosti Národního muzea jako jednoho z mála občanských spolků zatím nezrušených podle likvidačního zákona o sdružování občanů z roku 1951 podstatně omezovaly možnosti plynoucí z navazování a určující všechny archeologické nálezy jako majetek státu, který bylo možno pouze předat příslušnému muzeu. Formálně měly nyní i výtěžky výzkumů Archeologického ústavu v Čechách obohacovat zejména fondy NM, v praxi se to však dělo jen velmi omezeně.

Výsledkem bylo, že ve srovnání s minulostí podstatně vzrostl přísun sbírkového materiálu z vlastních (a velmi omezeně i z jiných) akcí, zatímco ze soukromých rukou naopak: objevily se ještě dary starších sbírek, nové však legálně vznikat nemohly a nahrazení dobrovolných darů povinným předáním náhodných nálezů nemělo předpokládaný efekt - nálezy zatajované nálezci začaly spíše mizet $\mathrm{v}$ soukromých rukou a nemožnost obchodování s nimi způsobila rozvoj černého trhu. $\mathrm{V}$ případech černého obchodu a vzácně se vyskytujícícho prodeje muzeím se stalo obvyklou pomůckou tvrzení o nalezení předmětu před rokem platnosti zákona. Takto poklesl význam propagace muzea jako vhodného místa k ukládání archeologických památek - to se nyní stalo povinností, ovšem jen velmi těžko vymahatelnou - a oficiálnost výzkumné činnosti rozšíríila mezeru mezi bádajícím odborně-institučním aparátem a většinou zdáli přihlížejícími zájemci.

O to větší význam pro vybudování stálého vztahu veřejnosti $\mathrm{k}$ muzeu a zdůraznění jeho významu pro společnost měla činnost zvaná tehdy vědecko-osvětová. Tvořily ji zejména dvě složky, výstavní a přednášková, nyní už častěji než dříve propojené. V obou těchto směrech dosáhlo období Jiřího Neustupného dosud nepřekonaných výsledků.

Nehledě na to, že v provizoriu prvních poválečných let přišly opět vhod krátkodobé výstavy jako nástroj urychlující po letech umlčení opětné navázání vztahu muzea s „obecenstvem“, základem veškeré činnosti na vědecko-osvětovém úseku byla stejně jako dříve expozice, tedy stálá (dlouhodobá) systematická výstava. Na vývoji expozice pravěku a raného středověku (prehistorie a protohistorie) v NM je nejzřetelněji vidět postup Jiřího Neustupného (zakladatele moderní české muzeologie), vždy podporovaného rostoucím odborným kolektivem oddělení, o oslovení návštěvníka, usnadnění recepce podávaných informací včetně zapojení techniky; pouze s interaktivními prvky se tehdy ještě nepočítalo. Toto úsilí a jeho výsledky byly podrobně popsány jinde. ${ }^{18}$

\section{Páté období (1968-1989)}

Zmínka o doprovodných akcích postupně ožívajících vlastním životem se týká přednášek a zejména přednáškových cyklů, jednoho z nejvýznamnějších kroků v historii vědecko-osvětové práce NM, vrcholného produktu v rámci tohoto typu prezentační činnosti muzeí, veřejností také vysoce oceňovaného.

Vzhledem k tomu, že stále slábnoucí činnost akviziční dále ztrácela význam pro vazbu na veřejnost (i když velké

\footnotetext{
${ }^{18}$ Karel SKLENÁŘ, Muzejni expozice v pojetí Jiřího Neustupného, Bulletin Státního ústavu památkové péče a ochrany př́rody, 1992, roč. 8, s. 145146; Karel SKLENÁŘ, Archeologické expozice Národního muzea: z Čech do Evropy - a zpátky?, Muzejní a vlastivědná práce 36/ Časopis Společnosti přátel starožitností 106, 1998, s. 15-30; Karel SKLENÁŘ, Pravěká a raně středověká archeologie.
} 
výzkumy v 70. a 80. letech doznívaly a rozmnožil se opět počet výzkumů malých, při nichž se pracovníci oddělení $\mathrm{v}$ rámci možností snažili o kontakt a propagaci $\mathrm{NM}$ ), nabývaly $\mathrm{v}$ tomto směru přednášky a cykly mnohem většího významu a staly se hlavním polem, na němž se veřejnost s muzeem i jako s celkem sbližovala. Cyklická forma se vyvinula $z$ př́ležitostných přednášek ke starším výstavám a expozicím, konaných kvůli prohloubení jejich naučného účinku, aniž by bylo zvláště sledováno navázání styku $\mathrm{s}$ veřejností. $\mathrm{O}$ cyklech prehistorického oddělení NM bylo nedávno psáno podrobněji, ${ }^{19}$ proto zde jen připomeňme, že tuto formu si oddělení vyzkoušelo už v předchozích letech krátkými výročními cykly přednášek svých členů o jimi vedených výzkumech $\mathrm{v}$ terénu nebo sledovaných odborných otázkách; jimi udržovalo dotyk se stálým okruhem svých prríznivců a informovalo je o výsledcích své činnosti.

Myšlenka mnohem rozsáhlejších cyklů se zrodila v souvislosti s vybudováním a otevřením poslední a největší expozice z roku 1966. Poněkud volnější poměry druhé poloviny 60 . let dovolily - samozřejmě pod egidou monopolní vědecko-politicko-vzdělávací instituce Socialistické akademie a jejího projektu Lidové univerzity - začít s vlastním projektem nazvaným Mimoškolní výuka prehistorie a protohistorie, jehož nositeli byli především autoři jednotlivých úseků nové expozice. Nešlo o jediný cyklus - ty probíhaly souběžně 2-3 každý rok - a také ne o prosté přednášky, nebot' lekce byly provázeny diapozitivy a někdy i filmy, v jedné řadě měly i podobu seminářů s dotazy a diskusí, zpočátku se konaly i závěrečné pohovory s osvědčením. O úspěšnosti tohoto uspořádání svědčí nejlépe fakt, že zájem veřejnosti umožnil, aby se program (s obměnami doplňujících cyklů) udržel plných dvacet let (1969-1989).

Spojení se společenským děním tu bylo dobře patrné: útěk od soudobé problematiky do vzdálenější minulosti, kam už nesahal normalizační tlak, přivedl k archeologii mnoho zájemců, uvolnění a rychlý návrat k aktuálním záležitostem po listopadu 1989 je zase odvedl. Nehledě na to, získalo oddělení pro sebe i pro NM řadu trvalejších příznivců, a dokonce podnítilo či rozvinulo zájem několika budoucích archeologů. Nikdy předtím ani potom neměla jeho činnost tak živou a setrvalou,,zpětnou vazbu“, ovšem specifické povahy: tak jako ve třetím období byla pilířem vztahu a komunikace s veřejností činnost výzkumná a ve čtvrtém expoziční (prezentace sbírkovým předmětem), v pátém převzala tuto úlohu osamostatněná prezentace slovem a obrazem. Akviziční činnost však zůstává v jejím stínu a vcelku nezaznamenává její předpokladatelný př́ínos.

\section{Šesté období (po roce 1989)}

Zatím poslední období ještě zdaleka neskončilo, není tedy snadné je charakterizovat. Základními činiteli jsou jednak změny obecnější povahy, jednak generační obměna pravěkého oddělení (dnes oddělení pravěku a antického starověku), která proběhla v 90. letech a znamenala doznění tradice éry Jiř́ho Neustupného. Vztah k veřejnosti a komunikace s ní se dostaly do nesnadné pozice: rezignace oddělení na terénní výzkumnou činnost je zbavila možnosti působit tímto směrem;

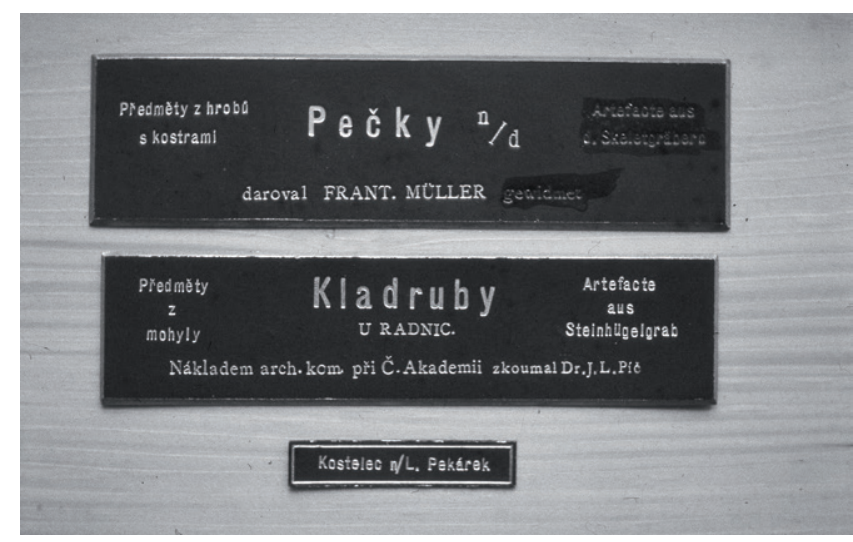

Obr. 5. Štítky na podstavcích exponátů v archeologické expozici prof. J. L. Píče v NM v 90. letech 19. století uváděly (zřejmě poprvé a jistě naposledy) vždy také jejich původ, resp. dárce.

ani mimovýzkumná akviziční činnost nenabízí velké možnosti v době, kdy proměny legislativy (majetkové určení nálezů) nebo její nedostatek spolu s novými společenskými jevy, jako je otevření trhu s archeologickými nálezy nebo stále se šírící užívání detektorů a opětná móda soukromých sbírek, podvazují tradiční sbírkotvorné formy (zejména pokud jde o dary). Přednášková činnost se v konkurenčním prostředí velkého města s jeho širokou kulturní nabídkou jeví jako slábnoucí činitel (vrchol svého významu již mají za sebou) a ani možnost osobního kontaktu zájemců o obor s profesionály nezastaví postupný úbytek posluchačského zájmu (regionální a lokální situace mimo velká města je dosud mnohem lepší). (Staro)novou cestu k veřejnosti nabízí po roce 1989 oživená Společnost Národního muzea - poměrně velký kolektiv interesentů a podporovatelů jeho činnosti -, ale ačkoli některá oddělení NM velmi úzce spolupracují s příslušnými sekcemi Společnosti, toto oddělení už při obnovení Společnosti počátkem 90 . let žádný zájem neprojevilo. Zbývá tedy za současné situace jedině cesta výstav a návazných akcí výstav tematických a krátkodobých, protože chystaná nová podoba stálé archeologické expozice NM, proti předchozímu stavu silně redukované, zatlačené do područí př́rodovědy, prostorově roztržené a od návaznosti přirozeného historického vývoje odtržené, velkou pomoc v tomto smyslu neslibuje. Zda a kdy nastane ve vztahu, resp. v komunikaci s veřejností sedmé období, bude záležet v budoucnu především na zájmu a ovšem i možnostech oddělení samého.

\section{Závěr o muzeu a veřejnosti}

Právě podaný přehled by bylo možné faktograficky rozmnožovat o další informace, ale i bez toho je jistě dostatečný, aby podal ucelený obraz vývoje vztahu archeologie NM k veřejnosti, přesněji řečeno ke společnosti, a ukázal, jakou úlohu v něm hrála výzkumná a akviziční činnost, obvykle v tomto ohledu podceňovaná. Lze sledovat, jak původní jednostranný a jednosměrný tok poučení pro publikum se postupně zpestřuje novými formami, až (poměrně nedávno) jeho emitenti dospívají k poznání, že to nestačí, že je třeba jej nahradit tokem obousměrným a od prezentace přejít ke komunikaci, aby muzeum mohlo plnit své úkoly v moderní společnosti.

\footnotetext{
${ }^{19}$ Karel SKLENÁŘ, , Mimoškolní výuka prehistorie a protohistorie“ (1969-1989) jako specifická forma popularizace vědy a komunikace Národního muzea s veřejností, Časopis Národního muzea, řada historická, 2017, roč. 186, č. 1-2, s. 29-54.
} 
Zároveň je ale patrné, jak prvek komunikace s veřejností byl v muzeu odedávna (resp. v NM zřetelněji od druhé z popsaných fází) přítomen, a to i ve směrech, jež zdánlivě komunikační potenciál nemají, konkrétně v akviziční činnosti.

Vývoj vztahu mezi muzeem a veřejností prošel tedy od 19. století delším vývojem, jehož konstantní charakteristikou je tendence od prezentace ke komunikaci, od jednosměrnosti k obousměrnosti stupňováním zájmu o návštěvníka, o jeho získání cestou zvyšování atraktivity muzea - a naopak nárůst návštěvnického zájmu, sledujícího trajektorii od zvědavosti přes poučení k zábavě s poučením. Tento vývoj lze na př́kladu archeologie sledovat $\mathrm{z}$ obou stran, jejichž stanoviska se navzájem ovlivňují.

Jednu stranu tvoří muzeum, určené zpočátku ke shromažd’ování a uchovávání „starožitností“; náhodnými cestami je doplňuje a veřejnosti předkládá jako snůšku kuriozit v podstatě bez poučného aspektu. Teprve postupně začínají muzejníci chápat jednak vzdělávací funkci či poslání svých sbírek, jednak užitečnost expozice pro probouzení zájmu veřejnosti - nejprve pasivního, pak ale možná aktivního ve smyslu obohacování sbírek i finanční pomoci. (Důležitou roli v tom směru hrál od poloviny století Archeologický sbor, který ale nebyl př́mou součástí muzea, i když je silně podporoval a byl jím podporován; právě prostřednictvím Sboru vstupovala do NM veřejnost s aktivním vztahem $\mathrm{k}$ jeho archeologické složce).

Ústřední muzeum musí hledat jiné cesty, zatím ještě stále v rámci výstavní prezentace. Objevují se doprovodné linie, rozšiřující informaci a zároveň často dokládající vlastní výzkumnou činnost: ${ }^{20}$ aktivním působením ve veřejnosti a na veřejnost získané hmotné prameny se zpětně obracejí na veřjnost prezentačními formami a posilují působení muzea na ni. Později se tyto linie oddělují od expozice samé, nastupují samostatnou cestu (zejména přednášková činnost, navazující konečně živější styk s veřejností a poprvé uvádějící do praxe živou zpětnou vazbu). Konečně moderní muzeum pochopí, že cílem není prostá prezentace sbírek, ale komunikace s veřejností na základě prezentace, a muzeum spojuje svou existenci se životem společnosti. V archeologii to znamená, že zájemci $\mathrm{z}$ řad veřejnosti se $\mathrm{z}$ víceméně pasivních konzumentů poučení stávají spolupracovníky muzejníků v terénu i v muzeu, spolutvưrcí sbírkového fondu a pomocníky při získávání prostředků na činnost. V detailu má samozřejmě tento obor svá specifika, která vztah k veřejnosti znesnadňují, problémem je zejména touha po provádění vlastních vykopávek v rozporu se zákonem, otázky vlastnictví nálezů a v novější době zejména činnost tzv. detektorářů. Zásadní potřeba dobrého vztahu $\mathrm{s}$ veřejností by však těmito problémy neměla být narušena.

Druhou stranu tohoto vztahu tvoří tedy veřejnost (v zásadě množina skutečných i potenciálních zájemců o obor z řad neprofesionálů a nemuzejníků), která se rovněž s dobou mění. Původně ji v NM (a nejen tady) zastupoval návštěvník-nenáročný konzument, prohlížející kuriozity bez vědomé touhy po poučení; podporu muzea a jeho činnosti (pokud v oboru nějaká byla), nebylo obvykle možno od něj očekávat. Veřejní podporovatelé muzea vesměs nebyli totožní s jeho návštěvníky, hrály tu roli jiné vztahy. Jednoznačně chyběl prvek komunikace, vyhrazený pouze vzácným návštěvám, osobním přátelům či cestujícím cizím učencům. Jinak se návštěvník občas dočkal náhodného výkladu nebo vysvětlení muzejního zaměstnance, zejména když se ve druhé polovině 19. století s nárůstem návštěvnosti rozmnožili hlídači v expozicích: odborníci si stěžovali, že hlídači podávají návštěvníkům nekvalifikované informace, jindy zase návštěvníci na hrubé odbytí při dotazech.

Éra velkých pražských výstav v závěru 19. století ukázala cestu pokroku ve vztazích vystavovatele k návštěvníkovi, zejména pokud šlo o to, nenabízet jen informaci a poučení, ale diváka zaujmout a vzbudit jeho zájem. O mnoho lépe se ale návštěvník NM necítil ani po otevření nové budovy: archeologická expozice byla sice pestřejší o doprovodné prvky, ale obecnější informace o vystavených nálezech nadále chyběly a záplava exponátů v mnoha patrech vitrín a regálů, vzrušující pro odborníka, navodila o běžného diváka nanejvýš dojem obrovského množství jednotvárného (převahou keramického) materiálu. Jestliže v období činnosti prof. Píče kulminovala spolupráce s veřejností, bylo to na zcela jiném základě společenských vztahů „Píčovy družiny“ a jejích sympatizantů; tato sít' zatlačila do pozadí i Archeologický sbor, ale s jejím rozpadem se situace vrátila do předchozích poměrů.

Změnu pak znamenalo teprve vrcholné období expozic J. Neustupného, které znásobilo formy vztahu k návštěvníkovi, jak už bylo popsáno výše. Bylo to nutné, protože návštěvník, ovlivněný rozvojem filmu od 20. let, televize od 50. let, o novějším technickém pokroku nemluvě, se postupně stává náročnějším a vybíravějším v nabídce zábavy kombinované někdy s poučením, takže pro muzeum je stále nesnadnější jej přilákat do expozic, a tím spíše pak k dalším doprovodným akcím. Zejména éra přednášek v konkurenčním prostředí velkých měst pomalu dožívá a jejich cílová skupina se během času redukuje.

Jeden podstatný činitel ovšem zůstává a nadále působí ve prospěch muzea: originalita jeho vystavených sbírek. I muzeum nejnovější doby a muzeum budoucnosti má jako hlavní úkol na základě sbírek prezentovat muzealizovanou skutečnost jako nezastupitelný originální a autentický zdroj poučení; v zájmu úspěšnosti tohoto konání volí samozřejmě postupy adekvátní době i očekávání veřejnosti, aniž by překračovalo hranici dělící jej od populistické veřejné atrakce. Vnímavější divák si však uvědomuje, že žádný nosič obrazové či textové informace mu nenahradí setkání s trojrozměrným dokladem památkové a kulturní hodnoty, působícím již svou existencí a svým autentickým svědectvím.

To je zásadní a pádný argument, proč jsou sbírky základem a důvodem existence muzea, zasluhujícím prioritní a kontinuální péči, proč má muzeum vždy klást důraz na vlastní odbornou sbírkotvornou (akviziční) činnost jako hlavní zdroj odborně kvalitních sbírek (v plné míře to platí o archeologickém terénním průzkumu a výzkumu) a proč vztah návštěvníka a muzea (přesněji kvalitního návštěvníka a kvalitního muzea) bude trvat i nadále; vše, co je nebo bude přidáno navíc - včetně interaktivity nebo ,virtuálního muzea“ jako nejnověji sledovaných cest za návštěvníkem - tuto skutečnost jistě ovlivní, ale její podstatu nezmění. ${ }^{21}$

\footnotetext{
${ }^{20}$ Souhrnně ji dokumentují materiály, jejichž přehled uveřejnil Karel SKLENÁ̌̆, Archiv nálezových zpráv oddělení prehistorie a protohistorie Národního muzea v Praze, Zprávy České archeologické společnosti, 2003, Suppl. 51 a zpracoval K. SKLENÁR̆, Pravěká a raně středověká archeologie.

${ }^{21}$ Text vznikl v rámci projektu Grantové agentury ČR „Národní muzeum v éře Československa“ č. GA16-02022S.
} 